\title{
Silicon and manganese on rice resistance to blast
}

\author{
Isaías Severino Cacique; Gisele Pereira Domiciano; Fabrício Ávila Rodrigues (*); Francisco \\ Xavier Ribeiro do Vale \\ Universidade Federal de Viçosa, Departamento de Fitopatologia, Laboratório da Interação Planta-Patógeno, Av. P. H. Rolfs s/n, \\ 36571-000 Viçosa (MG), Brasil. \\ (*) Corresponding author: fabricio@ufv.br
}

Received: Dec. 14, 2011; Accepted: May 14, 2012

\begin{abstract}
Blast, caused by the fungus Pyricularia oryzae, is the most important fungal disease of rice. The effect of silicon (Si) and manganese (Mn), and their interaction, on rice resistance to blast was investigated. Rice plants (cultivar "Metica 1") were grown in

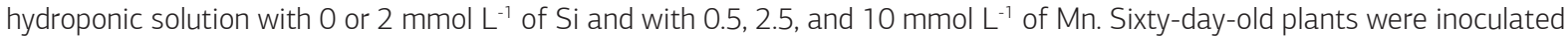
with a conidial suspension of $P$. oryzae and the incubation period (IP), the number of lesions (NL) per $\mathrm{cm}^{2}$ of leaf area, the lesion size (LS), and blast severity were evaluated. Blast severity was scored at 48, 72, 96, and 144 hours after inoculation and data were used to obtain the area under blast progress curve (AUBPC). Silicon concentration was significantly higher in leaf tissues of plants supplied with this element than on its absence, regardless of Mn rates. There was no significant difference in Si concentration among the Mn rates for both - Si and + Si treatments. The Mn concentration was significantly higher in the tissues of plants from the - Si treatment as compared to plants of the +Si treatment, but only at the rate of $10 \mathrm{mmol} \mathrm{L} \mathrm{L}^{-1}$ of $\mathrm{Mn}$. There was a significant increase in $\mathrm{Mn}$ concentration as the rates of this micronutrient increased from 0.5 to $10 \mathrm{mmol} \mathrm{L}^{-1}$ regardless of the Si treatments. The IP significantly increased in the + Si treatment. The Mn rates had no effect on the IP regardless of the Si treatments. The NL was significantly lower in the presence of Si regardless of the Mn rates. The $\mathrm{Mn}$ rates had no effect on NL regardless of the Si treatments. The addition of Si to the nutrient solution significantly reduced both LS and AUBPC regardless of Mn rates. However, in the absence of Si, the values for LS and AUBPC were significantly

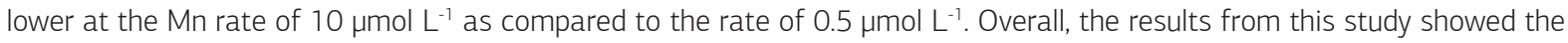
potential of Si to decrease blast development on rice regardless of the foliar concentration of Mn.
\end{abstract}

Key words: Oryza sativa, Pyricularia oryzae, leaf spot, mineral nutrition.

\section{Silício e manganês na resistência do arroz à brusone}

\section{Resumo}

A brusone, causada pelo fungo Pyricularia oryzae, é a doença fúngica mais importante do arroz. O efeito do silício (Si), do manganês (Mn) e da interação deles na resistência do arroz à brusone foi investigado. Plantas de arroz da cultivar Metica 1 foram cultivadas em solução nutritiva contendo 0 ou $2 \mathrm{mmol} \mathrm{L}^{-1}$ de Si e 0,5, 2,5 e $10 \mathrm{mmol} \mathrm{L}^{-1}$ de Mn. Aos 60 dias, as plantas foram submetidas à inoculação com uma suspensão de conídios de P. oryzae e foram avaliados o período de incubação (PI), o número de lesões (NL) por $\mathrm{cm}^{2}$ de área foliar, o tamanho de lesão (TL) e a severidade da brusone. A severidade da brusone foi avaliada às 48, 72, 96 e 144 horas após a inoculação e os dados foram usados para calcular a área abaixo da curva do progresso da brusone (AACPB). A concentração foliar de Si foi maior nas plantas supridas com Si. A concentração de Mn na solução nutritiva não interferiu na concentração de Si nas folhas das plantas de arroz. Houve aumento na concentração foliar de $\mathrm{Mn}$ à medida que a concentração desse micronutriente na solução nutritiva aumentou, independentemente da presença do Si. A presença de Si na solução nutritiva reduziu a concentração de Mn nas plantas cultivadas na dose de $10 \mathrm{mmol}^{-1}$ de Mn. O fornecimento de Si aumentou PI e reduziu o NL, o TI e a AACPB. As doses de Mn não tiveram efeito no PI e no NL, independentemente da presença ou não do Si. Na ausência de Si, os valores do TL e da AACPB foram significativamente menores para a dose de $10 \mu \mathrm{mol} \mathrm{L}{ }^{-1}$ de $\mathrm{Mn}$ em comparação com a dose de 0,5 $\mu \mathrm{mol} \mathrm{L^{-1 }}$ de $\mathrm{Mn}$. Os resultados deste estudo reforçam o potencial do Si em reduzir o progresso da brusone em arroz independentemente da concentração foliar de Mn.

Palavras-chave: Oryza sativa, Pyricularia oryzae, mancha foliar, nutrição mineral. 


\section{INTRODUCTION}

Blast, caused by the fungus Pyricularia oryzae (Cooke) Sacc., is the most important fungal disease of rice (Oryza sativa L.) and causes significant yield losses worldwide (Ou, 1985). An integrated control strategy for implementation in environments with high epidemic potential to blast includes the use of partially resistant cultivars, early sowing or seedlings transplanting, water and nitrogen management as well as seed treatment with fungicides or their foliar application (Ou, 1985). Silicon (Si) can decrease the intensity of blast as effectively as some fungicides, mainly because it has the potential to increase the partial resistance of cultivars to the same level observed in cultivars with complete resistance (DATNOFF et al., 1991). In this context, soil amendment with $\mathrm{Si}$ can be considered an effective strategy to decrease blast intensity, especially when rice is cultivated in Si-deficient soils. Some economically important rice diseases such as sheath blight, stem rot, leaf scald, leaf blight, and grain discoloration also had their intensities reduced with $\mathrm{Si}$ application on soil (Datnoff et al., 2007).

Many studies had investigated the mode of action of $\mathrm{Si}$ in reducing the intensities of diseases on several crops (DATNOFF et al., 2007). In rice, Si application has been associated with an increase in the density of silicified buliform cells in the leaf epidermis that helped to increase resistance against blast (Kim et al., 2002). According to Rodrigues et al. (2003), Si-mediated resistance to Pyricularia grisea in rice was related to the great accumulation of phenolic compounds. Rodrigues et al. (2005) also showed that in rice plants supplied with $\mathrm{Si}$, a differential accumulation of glucanase, peroxidases, and PR-1 transcripts was found in association with a higher concentration of phenolics compounds and lignin in plants supplied with Si. BRunings et al. (2009) also found that the involvement of chitinase genes in rice defense response against $P$. grised and also that phenylalanine ammonia-lyase and peroxidases genes were up-regulated after fungal infection in the absence of $\mathrm{Si}$.

Many important biochemical and physiological mechanisms in plants are affected by the Mn content on plant tissues (Thompson and Huber, 2007). Several enzymes in plants, such as the peroxidases, related to the production of phenolic compounds and flavonoids are dependent on $\mathrm{Mn}$ as co-factor (HAMOND-KosaK and JONES, 2000). Root rot, take-all, powdery mildew, leaf and stem rust on cereals; damping-off and wilt on cotton; late blight and scab on potato; leaf spots on soybean, and many other diseases in different crops had their intensities decreased by Mn (Thompson and Huber, 2007). Brown spot severity is negatively correlated with the content of Mn on rice leaf tissues (KaUr et al., 1979). However, the deficiency or toxicity of $\mathrm{Mn}$ can increase or decrease plant resistance against pathogens infection (EL-JAOUAL and Cox, 1998). Rice plants supplied with Si showed reduction on brown spot severity regardless of the presence of either low or high Mn rates (Zanáo et al., 2009). It is also known that plant tolerance to $\mathrm{Mn}$ toxicity can be increased in the presence of $\mathrm{Si}$ (HoriguchI, 1988).

The current study was undertaken to investigate the effects of $\mathrm{Si}$ and $\mathrm{Mn}$, and their interaction, on rice blast development.

\section{MATERIAL AND METHODS}

\section{Nutrient solution preparation}

The nutrient solution used in this study was prepared according to ZANÃo et al. (2009). The Mn rates used in this study were $0.5,2.5$, and $10 \mathrm{mmol} \mathrm{L}^{-1}$. Silicon was supplied as silicic acid, which was prepared by passing potassium silicate through a cation-exchange resin (Amberlite IR-120B, H+ form; Sigma-Aldrich, São Paulo) (MA et al., 2001). The Si rates used were 0 and $2 \mathrm{mmol} \mathrm{L}^{-1}$. The addition of silicic acid to the nutrient solution did not alter the $\mathrm{pH}$.

\section{Plant growth}

Rice seeds (cultivar 'Metica-1') were germinated on distilled water-soaked germitest paper (Fisher Scientific Inc., Pittsburgh, PA, USA) in a germination chamber at $25^{\circ} \mathrm{C}$ for five days. Germinated seedlings were transferred to plastic containers (25 cm in diameter) with one-halfstrength of the nutrient solution without the presence of $\mathrm{Si}$ or $\mathrm{Mn}$ for three days. After this period, plants were transferred to new plastic containers with $4 \mathrm{~L}$ of nutrient solution prepared using the different $\mathrm{Mn}$ and Si rates. The nutrient solution, without aeration, was changed every four days. The $\mathrm{pH}$ was checked daily and kept around 5.5 by using $\mathrm{NaOH}$ or $\mathrm{HCl}(1 \mathrm{M})$ when needed.

\section{Experimental design}

A two $\times$ three factorial experiment, consisting of two $\mathrm{Si}$ rates (referred thereafter as $-\mathrm{Si}$ and $+\mathrm{Si}$ treatments, respectively) and three $\mathrm{Mn}$ rates was arranged in a completely randomized design with four replications. The experiment was repeated and each experimental unit consisted of one plastic container with $4 \mathrm{~L}$ of nutrient solution and four rice plants.

\section{Inoculation procedure}

Plants were inoculated with $P$. oryzae after 60 days in hydroponic culture with the treatments. A pathogenic isolate 
of P. oryzae (CNPAF-1048) obtained from symptomatic rice plants and provided by Dr. Marta Cristina C. Filippi (Embrapa, Rice and Beans Research Center) was used to inoculate the plants. This isolate was preserved on filter paper at $-80^{\circ} \mathrm{C}$ (Dhingra and Sinclair, 1995). Pieces of filter paper containing fungal mycelia were transferred to Petri dishes with potato dextrose agar (PDA). After three days, PDA plugs containing fungal mycelia were transferred to Petri dishes with oat medium. Petri dishes were kept in a growth chamber at $25^{\circ} \mathrm{C}$ with a $12 \mathrm{~h}$ photoperiod for 15 days. A conidial suspension of $P$. oryzae $\left(1.2 \times 10^{5}\right.$ conidia $\mathrm{mL}^{-1}$ ) was applied as a fine mist to the adaxial leaf blades of three marked leaves per plant until runoff using a VL Airbrush atomizer (Paasche Airbrusch Co., Chicago, USA). Gelatin $(1 \%, w / v)$ was added to the sterile water to aid conidial adhesion to the leaf blades. Immediately after inoculation, plants were transferred to a mist chamber at $25 \pm 2{ }^{\circ} \mathrm{C}$ with an initial $24 \mathrm{~h}$ dark period. After this period, plants were incubated using a $12 \mathrm{~h}$ photoperiod under $c a .160 \mathrm{mmol} \mathrm{m}^{-2} \mathrm{~s}^{-1}$ provided by cool-white fluorescent lamps. The relative humidity inside the mist chamber was $95 \pm 2 \%$ throughout the experiments. Plants were kept inside the mist chamber for the duration of the experiments.

\section{Quantification of some components of host resistance}

The incubation period (IP), the number of lesions (NL) per $\mathrm{cm}^{2}$ of leaf area, the lesion size (LS), and disease severity were evaluated on the $5^{\text {th }}$ and $6^{\text {th }}$ leaves from the main tiller of each plant. The IP (in hours) was scored by examining these leaves every 6 hours after inoculation (hai). The NL was counted at five randomized places on the two marked leaves per plant using a handheld microscope $(20 \times)$ at 72 hai. Blast severity on the leaves of each plant was scored at 48, 72, 96, and 144 hours after inoculation (hai) by using a scale based on the percentage of diseased leaf area (IRRI, 1996). Area under blast progress curve (AUBPC) for each leaf in each plant was computed using the trapezoidal integration of blast progress curve over time according to SHANER and Finney (1977).

\section{Leaf tissue analysis for Si and Mn concentrations}

After the experiments, leaves were collected from plants of each treatment, washed in deionized water, dried during $72 \mathrm{~h}$ at $65^{\circ} \mathrm{C}$ and ground to pass through a 40 -mesh screen with a Thomas-Wiley mill (Thomas Scientific, Swedesboro, NJ, USA). Silicon in leaf tissue was determined by a colorimetric analysis on $0.1 \mathrm{~g}$ of dried and alkali digested tissue (Korndörfer et al., 2004). Dried leaf tissue was digested with a nitric-perchloric solution $(3: 1, \mathrm{v} / \mathrm{v})$ and the concentration of $\mathrm{Mn}$ was determined by atomic absorption spectrophotometry.

\section{Data analysis}

Cochran's test for homogeneity of variance (Gomez and Gomez, 1994) indicated that the data from the two experiments could be pooled for data analysis. The experimenttreatment interactions were not significant $(\mathrm{p}>0.05)$. Data were subjected to the analysis of variance (ANOVA) and the treatment means compared with Tukey's test $(\mathrm{p} \leq 0.05)$ using the software SAEG 5.0 (UFV, Viçosa, Minas Gerais State, Brasil). Data from Si and Mn concentrations in leaf tissues were correlated with the components of resistance evaluated.

\section{RESULTS}

The Si concentration was higher in the tissues of plants supplied with Si as compared to those that were not supplied with this element, regardless of $\mathrm{Mn}$ rates (Table 1). There was no significant difference in Si concentration among the Mn rates for both $-\mathrm{Si}$ and $+\mathrm{Si}$ treatments. The Mn concentration was higher in the tissues of plants from the -Si treatment as compared to plants of the $+\mathrm{Si}$ treatment, but only at the rate of $10 \mathrm{mmol} \mathrm{L}^{-1}$ of Mn. There was a significant increase in $\mathrm{Mn}$ concentration as the rates of this micronutrient increased from 0.5 to $10 \mathrm{mmol} \mathrm{L}^{-1}$ regardless of the $\mathrm{Si}$ treatment (Table 1 ).

The IP on rice leaves increased in the $+\mathrm{Si}$ treatment (Table 2). The NL was significantly lower in the presence of Si regardless of the Mn rates (Table 2). The Mn rates had no effect on the IP and on NL regardless of the Si treatments (Table 2). The addition of Si to the nutrient solution reduced both LS and AUBPC regardless of $\mathrm{Mn}$ rates (Table 2). However, in the absence of $\mathrm{Si}$, the values for LS and AUBPC were significantly lower at the Mn rate of $10 \mu \mathrm{mol} \mathrm{L}^{-1}$ as compared to the rate of $0.5 \mu \mathrm{mol} \mathrm{L}-1$.

Table 1. Concentrations of silicon ( $\mathrm{Si}$ ) and manganese $(\mathrm{Mn})$ in leaf tissue of rice plants grown in hydroponic culture containing different rates of these elements

\begin{tabular}{|c|c|c|c|c|}
\hline \multirow{2}{*}{$\begin{array}{c}\text { Mn } \\
\left.(\mu \mathrm{mol} \mathrm{L})^{-1}\right)\end{array}$} & \multicolumn{2}{|c|}{ Si $\left(\mathbf{g ~ k g}^{-1}\right)$} & \multicolumn{2}{|c|}{$\operatorname{Mn}\left(\mathrm{mg} \mathrm{kg}^{-1}\right)$} \\
\hline & $-\mathbf{S i}$ & $+\mathbf{S i}$ & $-S i$ & $+\mathbf{S i}$ \\
\hline 0.5 & $6.36 \mathrm{aB}$ & $30.02 \mathrm{aA}$ & $49.70 \mathrm{cA}$ & $48.30 \mathrm{cA}$ \\
\hline 2.5 & $6.37 \mathrm{aB}$ & $34.12 \mathrm{aA}$ & $98.08 \mathrm{bA}$ & $89.85 \mathrm{bA}$ \\
\hline 10.0 & $6.43 \mathrm{aB}$ & $33.32 \mathrm{aA}$ & $338.23 \mathrm{aA}$ & $230.53 \mathrm{aB}$ \\
\hline CV (\%) & \multicolumn{2}{|c|}{13.3} & \multicolumn{2}{|c|}{25.2} \\
\hline
\end{tabular}

For each variable, means within a column followed by the same lower-case letter or means within a row followed by the same upper-case letter are not significantly different $(\mathrm{p}=0.05)$ as determined by Tukey's test. Data shown are from two pooled experiments. CV: coefficient of variation. $(n=48)$. 
Table 2. Incubation period (IP), number of lesions per $\mathrm{cm}^{2}$ of leaf area (NL), lesion size (LS) and area under blast progress curve (AUBPC) in rice plants grown in nutrient solution made with different rates of silicon $(\mathrm{Si})$ and manganese $(\mathrm{Mn})$

\begin{tabular}{|c|c|c|c|c|c|c|c|c|}
\hline \multirow{3}{*}{$\begin{array}{l}\text { Mn rates } \\
\left(\mathrm{mmol} \mathrm{L}^{-1}\right)\end{array}$} & \multicolumn{8}{|c|}{ Components of host resistance } \\
\hline & \multicolumn{2}{|c|}{ IP (h) } & \multicolumn{2}{|c|}{ NL } & \multicolumn{2}{|c|}{ LS (mm) } & \multicolumn{2}{|c|}{ AUBPC } \\
\hline & $-\mathbf{S i}$ & $+\mathrm{Si}$ & $-\mathbf{S i}$ & $+\mathrm{Si}$ & $-\mathrm{Si}$ & $+\mathrm{Si}$ & $-\mathrm{Si}$ & $+\mathrm{Si}$ \\
\hline 0.5 & $37.0 \mathrm{aB}$ & $42.3 \mathrm{aA}$ & $14.9 \mathrm{aA}$ & $2.8 \mathrm{aB}$ & $1.16 \mathrm{bA}$ & $0.31 \mathrm{aB}$ & $402.7 \mathrm{aA}$ & $27.5 \mathrm{aB}$ \\
\hline 2.5 & $37.7 \mathrm{aB}$ & $42.1 \mathrm{aA}$ & $12.4 \mathrm{aA}$ & $2.6 \mathrm{aB}$ & $1.33 \mathrm{cA}$ & $0.25 \mathrm{aB}$ & 207.6 bA & $38.3 \mathrm{aB}$ \\
\hline 10.0 & $38.0 \mathrm{aB}$ & $42.7 \mathrm{aA}$ & $11.6 \mathrm{aA}$ & $2.4 \mathrm{aB}$ & $0.93 \mathrm{aA}$ & $0.24 \mathrm{aB}$ & $233.1 \mathrm{bA}$ & $39.2 \mathrm{aB}$ \\
\hline CV (\%) & \multicolumn{2}{|c|}{3.7} & \multicolumn{2}{|c|}{36.0} & \multicolumn{2}{|c|}{16.4} & \multicolumn{2}{|c|}{27.5} \\
\hline
\end{tabular}

For each variable, means within a column followed by the same lower-case letter or means within a row followed by the same upper-case letter are not significantly different $(\mathrm{p}=0.05)$ as determined by Tukey's test. Data shown are from two pooled experiments. CV: coefficient of variation. $(n=48)$.

Table 3. Pearson correlation coefficients between the incubation period (IP), number of lesions (NL) per $\mathrm{cm}^{2}$ of leaf area, lesion size (LS), and area under blast progress curve (AUBPC) with the concentrations of silicon $(\mathrm{Si})$ and manganese $(\mathrm{Mn})$ in rice leaf tissue

$\begin{array}{lcc}\text { Components of resistance } & \text { Si } & \text { Mn } \\ \text { IP } & 0.95^{* *} & -0.06^{\text {ns }} \\ \text { NL } & -0.83^{* *} & -0.10^{\text {ns }} \\ \text { LS } & -0.92^{* *} & -0.05^{\text {ns }} \\ \text { AUBPC } & -0.84^{* *} & -0.01^{\text {ns }}\end{array}$

"Significant at $\mathrm{p} \leq 0.05$. ${ }^{\mathrm{n} n}$ non significant. Data are from pooled experiments. $(\mathrm{n}=48)$.

The concentration of $\mathrm{Si}$ was negatively and significantly correlated with the variables NL, LS, and AUBPC and positively correlated with IP (Table 3 ). The concentration of Mn did not correlate with any of these variables.

\section{DISCUSSION}

This study not only brings support to the concept that $\mathrm{Si}$ can increase rice resistance to blast, but also provides the first data showing the effect of $\mathrm{Si}$ interacting with the micronutrient $\mathrm{Mn}$ on blast development. It is known that rice resistance to blast can be significantly increased when $\mathrm{Si}$ concentration on leaf tissues are kept within adequate levels (Datnoff et al., 2007). The Si concentration of $16 \mathrm{~g} \mathrm{~kg}^{-1}$ was sufficient to decrease blast severity on rice plants (SEebold et al., 2001). In the present study, $\mathrm{Si}$ concentration on leaf tissues of plants supplied with this element was, on average, $33 \mathrm{~g} \mathrm{~kg}^{-1}$, across Mn rates, which was sufficient to negatively impact blast development. The Mn concentrations on leaf tissues at the highest $\mathrm{Mn}$ rate were kept within adequate levels according to Fageria (1984), which ranges from 30 to $600 \mathrm{mg} \mathrm{kg}^{-1}$ and no symptoms of Mn toxicity were observed on leaves of rice plants grown at the rate of $10 \mathrm{mmol} \mathrm{L}^{-1}$ of $\mathrm{Mn}$.

All components of resistance evaluated were affected by the highest concentration of $\mathrm{Si}$ on leaf tissues. For instance, the LS and the AUBPC were the only components of resistance affected by the highest Mn rate. The IP was longest at the highest Si concentration on leaf tissue, but was not affected by Mn. The increase in IP may indirectly reflect a delay in the time needed by $P$. oryzae to ensure penetration at the epidermal cell. According to SEEBOLD et al. (2001), the IP for rice blast increased as the rates of $\mathrm{Si}$ added to the soil increased. On the other hand, Rodrigues et al. (2001) did not observe any significant effect of $\mathrm{Si}$ in increasing the IP of sheath blight in rice, probably because Rhizoctonia solani was able to penetrate through the stomata. In the case of $P$. grisea, the infections take place through the epidermal cells with the formation of an apressorium (HowARD, 1991) and the high Si concentration on rice leaf tissues may negatively impact fungus penetration because of its polymerization beneath the cuticle (Yoshida et al., 1962). KIm et al. (2002) investigated some of the cellular features of Si-mediated resistance to blast and observed that the epidermal cell wall thickness was not significantly affected by Si. However, the thickness ratios of silica layers to epidermal cell walls were much higher in the resistant cultivar than in the susceptible cultivar. Although the fortification of epidermal cell walls was considered the main cause for the reduced number of leaf blast lesions, no evidence in relation to the physical impedance offered by the fortified cell wall was given to the penetration peg of P. grisea (KIm et al., 2002). The number of lesions of brown spot and their size were reduced on leaves of rice plants grown in different soils containing high levels of Mn (BABA and TAKAHASHI, 1957). Rodrigues et al. (2005) showed that in rice plants supplied with $\mathrm{Si}$, differential accumulations of glucanases, peroxidases, and PR-1 transcripts were found in association with high concentrations of phenolic compounds and lignin. BRunings et al. (2009) reported the involvement of chitinase genes in rice defense response against infection by $P$. grised and also that phenylalanine ammonia-lyases and peroxidases genes were up-regulated after fungal infection in the absence of $\mathrm{Si}$.

In the presence of $\mathrm{Si}, \mathrm{Mn}$ had no effect on the components of resistance evaluated. However, on the absence of $\mathrm{Si}$, blast was negatively affected in the highest $\mathrm{Mn}$ rate. ZANÁo et al. (2009) observed that rice plants supplied with $\mathrm{Si}$ showed reduction on brown spot severity even at the lowest $\mathrm{Mn}$ rate. In the presence of $\mathrm{Si}$, some plant species show tolerance to Mn toxicity (HoriguchI, 1988). Blast severity on rice can be reduced by Si (Datnoff et al., 2007). The partial resistance of rice cultivars can be increased by $\mathrm{Si}$ to levels comparable to those observed in cultivars with 
complete resistance (Rodrigues et al., 2001). SEebold et al. (2001) demonstrated for rice blast that the number of sporulating lesions, lesion size, lesion expansion rate, severity, and the number of conidia per lesion were significantly reduced as the Si rates increased in the soil. An increase in lignin and soluble phenolic compounds production and the inhibition of lytic enzymes produced by the pathogen promoted by high content of $\mathrm{Mn}$ on rice leaf tissues was associated with the decrease in brown spot severity (GRAHAM and WeвB, 1991). The use of an intermediate Mn rate when $\mathrm{Si}$ was absent of the nutrient solution helped to reduced the brown spot symptoms while rice plants supplied with $\mathrm{Si}$ were resistant to blast regardless of $\mathrm{Mn}$ rates. It appears that the concentration of $\mathrm{Mn}$ in plant tissue must be at an adequate level to confer host resistance to diseases. A reduced concentration of aminoacids, phenolic compounds, and lignin were found to be low on plants deficient in $\mathrm{Mn}$ making them more susceptible to diseases (Brown et al., 1984; Burnell, 1988). Indeed, isolates of $P$ grisea unable to oxidize Mn were less aggressive on rice leaves similarly to what was reported by the wheat-Gaeumannomyces graminis var. tritici pathosystem (Thompson and Huber, 2007).

\section{CONCLUSION}

Blast progress was lower in leaves of rice plants supplied with $\mathrm{Si}$ regardless of the foliar concentration of $\mathrm{Mn}$. In the absence of $\mathrm{Si}$, high Mn concentration on leaf tissues contributed to decrease blast symptoms.

\section{REFERENCES}

BABA, I.; TAKAHASHI, Y. Growth and susceptibility to Helmintosporium leaf spot disease of rice plants grown in different soils under different water temperature. Journal of Agricultural Meteorology, v.13, p.41-44, 1957.

BROWN, P.H.; GRAHAM, R.D.; NICHOLAS, J.D. The effects of manganese and nitrate supply on the levels of phenolics and lignin in young wheat plants. Plant and Soil, v.81, p.437-440, 1984.

BRUNINGS, A.M.; DATNOFF, L.E.; MA, J.F.; MITANI, N.; NAGAMURA, Y.; RATHINASABAPATHI, B.; KIRST, M. Differential gene expression of rice in response to silicon and rice blast fungus Magnaporthe oryzae. Annals of Applied Biology, v.155, p.161-170, 2009.

BURNELL, J.N. The biochemistry of manganese in plants. In: GRAHAM, R.D.; HANNAM, R.J.; UREN, N.C. (Ed). Manganese in soils and plants. Dordrecht: Kluwer Academic, 1988. p.125-137.

DATNOFF, L.E.; RAID, R.N.; SNYDER, G.H.; JONES, D.B. Effect of calcium silicate on blast and brown spot intensities and yields of rice. Plant Disease, v.75, p.729-732, 1991.
DATNOFF, L.E.; RODRIGUES, F.A.; SEEBOLD, K.W. Silicon and plant disease. In: DATNOFF L.E.; ELMER, W.H.; HUBER, D.M. (Ed.). Mineral nutrition and plant disease. St. Paul: The American Phytopathological Society Press, 2007. p.233-246.

EL-JAOUAL, T.; COX, D.A. Manganese toxicity in plants. Journal of Plant Nutrition, v.21, p.353-386, 1998.

DHINGRA O.D.; SINCLAIR J.B. Basic plant pathology methods. Boca Raton: Lewis Publisher, 1995. 434p.

FAGERIA, N.K. Adubação e nutrição mineral da cultura do arroz. Goiânia: EMBRAPA-CNPAF, 1984. 341p.

GOMEZ K.A.; GOMEZ A.A. Statistical Procedures for Agricultural Research. 2. ed. New York: John Wiley, 1984. 680p.

GRAHAM R.D.; WEBB M.J. Micronutrients and disease resistance and tolerance in plants. In: MORTVEDT, J.J.; COX, F.R.; SHUMAN, L.M.; WELCH, R.M. (Ed.). Micronutrients in agriculture. 2. ed. Madison: Soil Science Society of America, 1991. p.329-370.

HAMOND-KOSAC, K.; JONES, J.D.G. Responses to plant pathogen In: BUCHANAM, B.B.; GRUISSEM, W.; JONES, R.L. (Ed.). Biochemistry and molecular biology of plants. Wiley: Rockville, 2000. p.1102-1157.

HORIGUCHI, T. Mechanism of manganese toxicity and tolerance of plants. IV. Effects of silicon on alleviation of manganese toxicity of rice plants. Soil Science and Plant Nutrition, v.34, p.65-73, 1998.

HOWARD, R.J. Penetration of hard substrates by a fungus employing enormous turgor pressures. Microbiology, v.88, p.11281-11284, 1991.

INTERNATIONAL RICE RESEACH INSTITUTE (IRRI). Standard Evaluation System for Rice. $4^{\text {th }}$ Edition. Los Baños: The Philippines, 1996. 394p.

KAUR, P., KAUR, S., PADMANABHAN, S.Y. Effect of manganese and iron on incidence of brown spot disease of rice. Indian Phytopathology, v.32, p.287-288, 1979.

KIM, S.G.; KIM, K.W.; PARK, E.W.; CHOI, D. Silicon-induced cell wall fortification of rice leaves, a possible cellular mechanism of enhanced host resistance to blast. Phytopathology, v.92, p.1095$1103,2002$.

KORNDÖRFER, G.H.; PEREIRA, H.S.; NOLA, A. Análise de silício: solo, planta e fertilizante. Uberlândia: Grupo de Pesquisa em Silício, ICIAG-Universidade Federal de Uberlândia, 2004. 28p. (Boletim Técnico, 1)

MA, J.F.; GOTO, S.; TAMAI, K.; ICHII, M. Role of root hairs and lateral roots in silicon uptake by rice. Plant Physiology, v.127, p.1773-1780, 2001.

OU, S.H. Rice diseases. $2^{\text {nd }}$ Edition. Kew: Commonwealth Mycological Institute, 1985. 380p. 
RODRIGUES, F.A.; BENHAMOU, N.; DATNOFF, L.E.; JONES, J.B.; BÉLANGER, R.R. Ultrastructural and cytochemical aspects of silicon-mediated rice blast resistance. Phytopathology, v.93, p.535-546, 2003.

RODRIGUES, F.A.; DATNOFF, L.E.; KORNDÖRFER, G.H.; SEEBOLD, K.W.; RUSH, M.C. Effect of silicon and host resistance on sheath blight development in rice. Plant Disease, v.85, p.827-832, 2001.

RODRIGUES, F.A.; JURICK, W.M.; DATNOFF, L.E.; JONES, J.B.; ROLLINS J.A. Silicon influences cytological and molecular events in compatible and incompatible rice-Magnaporthe grisea interactions. Physiological and Molecular Plant Pathology, v.66, p.144-159, 2005.

SEEBOLD, K.W.; KUCHAREK, T.A.; DATNOFF, L.E.; CORREAVICTORIA, J.F.; MARCHETTI, M.A. The influence of silicon on components of resistance to blast in susceptible, partially resistant, and resistant cultivars of rice. Phytopathology, v.91, p.63-69, 2001.
SHANER, G.; FINNEY, R.E. The effect of nitrogen fertilization on the expression of slow-mildewing resistance in knox wheat. Phytopathology, v.70, p.1183-1186, 1977.

THOMPSON, I.A.; HUBER, D.M. Manganese and plant disease. In: DATNOFF L.E.; ELMER, W.H.; HUBER, D.M. (Ed.). Mineral nutrition and plant disease. St. Paul: The American Phytopathological Society Press, 2007. p.139-153.

YOSHIDA, S.S.; OHNISHI, Y.; KITAGISHI, K. Chemical forms, mobility, and deposition of silicon in rice plant. Soil Science and Plant Nutrition, v.8, p.107-111, 1962.

ZANÃO JÚNIOR L.A.; RODRIGUES F.A.; FONTES, R.L.F.; KORNDÖRFER, G.H.; NEVES, J.C.L. Rice resistance to brown spot mediated by silicon and its interaction with manganese. Journal of Phytopathology, v.157, p.73-78, 2009. 